\title{
KONSEP BRAIN, BEAUTY AND BEHAVIOR (3B) PADA PROFESI PUBLIC RELATIONS
}

\author{
Intan Mustafa \\ intanbahy5@gmail.com \\ Universitas Nusa Nipa Maumere
}

\begin{abstract}
Qualification of Public Relations becomes a basic requirement for a company or organization. One of them is through the work of the front office in the banking industry. This study intends to examine the concept of 3B (Brain, beauty and behavior) into a work system based on Public Relations qualifications. with data collection techniques through interviews and observations to customers and front office employees at several banks in Sikka Regency. The results of data analysis carried out related to the implementation of the $3 \mathrm{~B}$ concept are categorized based on the public relations qualifications namely: 1). Brain (A. ability to communicate ability in communication management based on 2 things, namely, knowledge and skill, b) Ability to Organize: Front officers are able to act as problem solvers in finding strategic solutions to problems related to products and services from banks. 2) Beauty (a. personal integrity, which includes 2 things namely a modest personality, and friendly and dress ethics, which contain aesthetic and ethical values 3) Behavior (a. Ability to get on with people, relationships based on customer satisfaction and providing good service. b. Imagination, insight and understanding of customer characteristics and mastering concepts, implementation in solving each problem responsibly and quickly). From the results of the research conducted, it was found that the front office performance in the banking industry has so far reflected the standard of a public relations officer.
\end{abstract}

\section{Keywords: Brain, Beauty and Behavior, Public Relations}

\begin{abstract}
ABSTRAK
Kualifikasi Public Relations menjadi kebutuhan mendasar bagi suatu perusahaan atau organisasi. Salah satunya melalui kerja front office pada industri perbankan. Penelitian ini bermaksud mengkaji konsep 3B (Brain, beauty and behavior) ke dalam sebuah sistem kerja yang berdasarkan kualifikasi Public Relations. Penelitian ini menggunakan pendekatan deskriptif kualitatif, dengan teknik pengumpulan data melalui wawancara dan observasi kepada nasabah dan karyawan front office pada beberapa bank yang ada di Kabupaten Sikka. Hasil analisis data yang dilakukan terkait implementasi konsep 3B dikategorikan berdasar pada kualifikasi public relations, yakni: 1). Brain (a. ability to communicate, yakni kemampuan dalam manajemen berkomunikasi berdasarkan pada 2 hal, yakni knowledge dan skill, b. Ability to Organize: Front office mampu berperan sebagai problem solver dalam mencari solusi yang strategis pada masalah terkait produk dan jasa dari bank. 2) Beauty (a. personal integrity, yang mencakup 2 hal yaitu kepribadian yang bersahaja, serta ramah dan etika berbusana, yang mengandung nilai estetika serta etis. 3) Behavior (a. Ability to get on with people, relasi berdasarkan kepada kepuasan nasabah serta memberikan good service. b. Imagination, wawasan dan pemahaman terhadap karakteristik nasabah serta menguasai konsep, implementasi dalam pemecahan setiap masalah secara tanggap dan cepat). Dari hasil penelitian yang dilakukan ditemukan bahwa kinerja front office pada industri perbankan sejauh ini mampu mencerminkan standar seorang public relations officer.
\end{abstract}


Kata Kunci: Brain, Beauty and Behavior, Public Relations

\section{PENDAHULUAN}

Public Relations sebagai aktifitas komunikasi yang terencana memiliki peran penting dalam tatanan manajemen dalam suatu organisasi. Keberadaan Public Relations memudahkan suatu perusahaan untuk berkomunikasi dengan stakeholdernya, baik itu dalam skala internal maupun eksternal relations. Melalui berbagai kegiatan yang terencana, Public Relations diharapkan dapat mencapai tujuan perusahaan, yakni menciptakan serta mempertahankan keberadaan perusahaan sehingga menimbulkan adanya good will (citra yang baik) mutual understanding (saling pengertian), dan mutual confidence (saling mempercayai) antara organisasi dengan publik, begitupun sebaliknya. Professional Public Relations Officer dituntut dapat menjadi mediator, kreator, konseptor, sekaligus komunikator dengan cara mengoptimalkan dan memberdayakan apa yang ada dan berkembang dalam masyarakat. Hal ini sejalan dengan pengertian dari komunikasi pemasaran yang merupakan usaha untuk menyampaikan pesan kepada publik terutama konsumen sasaran mengenai keberadaan produk di pasar, sehingga mempunyai andil dalam kesadaran merek bagi perusahaan. (Kotler \& Keller, 2009:37).

Public Relations merupakan satu mekanisme yang dapat menghubungkan produsen dengan konsumen atau organisasi dengan publiknya secara efektif dan dapat menciptakan ketergantungan organisasi dengan publiknya (Yulianita, 2001:11). Meskipun penempatan PR tidak harus berada pada bagian state of being atau divisi khusus dalam sebuah korporasi, namun kemampuan technique of communication menjadi suatu tuntutan yang wajib dimiliki oleh setiap karyawan yang berada pada tingkatan management hingga Top Excecutive. Menurut Rachmat Kriyantono, (2008:21), fungsi atau peranan Public Relations adalah tentang harapan publik terhadap apa yang seharusnya dilakukan oleh Public Relations sesuai dengan kedudukannya sebagai seorang Public Relations Officer. Jadi, Public Relations dikatakan berfungsi apabila dia mampu melakukan tugas dan kewajibannya dengan baik, berguna atau tidak dalam menunjang tujuan 
perusahaan dan menjamin kepetingan publik.

Salah satu contoh implementasi kerja PRO adalah pada karyawan Front Office pada industri jasa keuangan perbankan. Pertumbuhan dan perkembangan industri perbankan di tengah masyarakat, menuntut kehandalan setiap bagian atau lini yang bekerja ekstra untuk mempertahankan atmosfir kerja yang siap bersaing. Sistem perekrutan menjadi indikator penting dalam menilai standar dari kualitas sumber daya manusia (SDM) calon karyawannya. Biasanya setiap bank menerapkan standar yang berbeda disesuaikan dengan tingkat kebutuhan dan target pencapaian. Perusahaan perbankan memiliki standart yang cukup tinggi dalam sistem perekrutan karyawan, khususnya yang menempati posisi depan seperti satuan pengamanan (satpam), teller serta customer service. Penerapan standar kualifikasi yang cukup tinggi dalam mempekerjakan karyawan front office dikarenakan pada lini atau bagian ini langsung berhubungan dengan pelanggan (customer). Yang diharapkan dari kualifikasi pada pekerja Front Office adalah interprestasi dari konsep diri yang excellence dalam berhadapan dengan nasabah. Untuk menerjemahkan citra diri yang excellence inilah, kehadiran konsep 3B (Brain, Beauty and Behavior) dikaji berdasarkan lingkup kerja PR untuk dijadikan kategorisasi tersendiri guna mengukur standar kualifikasi PR secara professional dengan mengintegrasikan 3 definisi, yakni pengetahuan, (expertise), keahlian (skill) dan etika profesi (ethics).

Kehadiran media digital saat ini turut berkontribusi terhadap kebebasan interpretasi khalayak pada keberadaan sebuah perusahaan atau organisasi. Berbagai kemudahan informasi disajikan tanpa melalui filter yang jelas. PR di era digital dituntut untuk mampu menjadi problem solver pada beberapa kasus terkait asumsi masyarakat yang terlanjur memercayai kualitas atau mutu suatu produk atau jasa yang ditawarkan dari suatu perusahaan tanpa melalui suatu uji kelayakan secara langsung sebagai customer atau konsumen pada perusahaan atau organisasi tersebut. Implikasinya adalah hadirlah tipe masyarakat yang kritis, reaktif dan responsif terkait produk dan jasa suatu perusahaan. Oleh karena itu, keberadaan front office menjadi indikator dalam perumusahan kualitas suatu perusahaan melalui kerja customer service.

Suatu problem yang cukup dilematis, ketika pertanyaan terkait konsep 3B ini ditujukan kepada 
pekerja front office, apakah sudah terpenuhi semua kriteria dari konsep 3B tersebut? Pada kenyataannya bahwa masih banyak yang memiliki kesalahan tafsir terkait pemahaman mengenai brain, beauty dan behavior. Brain sendiri mengandung pengertian tentang kecerdasan, namun apakah kecerdasan bagi seorang pekerja front office merupakan kecerdasan berdasarkan kemampuan akademik atau terkait dengan tuntutan untuk harus berwawasan luas? Sedangkan konsep Beauty yang merupakan definisi cantik sebenarnya mengacu kepada postur tubuh yang ideal, dengan pemenuhan kriteria seperti, memiliki postur tinggi, berkulit putih mulus, sampai perawakan yang sexy. Sedangkan behavior, tidak hanya cukup dengan kata "baik" dalam bertindak dan berperilaku.

Mengacu kepada realitas di atas, penting untuk mengolaborasikan implementasi dari Brain, Beauty and Behavior yang mengacu kepada kualifikasi $P R$, yang mana menurut Soemirat dan Elvinaro Ardianto (2012:159-160), kualifikasi profesi Public Relations itu sendiri mencakup Ability to communicate (kemampuan berkomunikasi), Ability to organize (kemampuan mengorganisasi), Ability to get on with people (kemampuan bergaul), Personal integrity (berkepribadian jujur). Imagination (memiliki imajinasi yang kuat). Pada penelitian ini, peneliti berupaya memetakan kelima kualifikasi PR ini ke dalam konsep 3B yang mewakili, brain, beauty dan behavior khusus pada pekerja font office industri bank.

\section{METODE PENELITIAN}

Metode penelitian adalah proses, prinsip dan prosedur yang kita gunakan untuk mendekati problem dan mencari jawaban. Dengan kata lain metode penelitian adalah suatu pendekatan ilmu untuk mengkaji topik penelitian. (Mulyana, 2004:30)

Pendekatan yang digunakan dalam penelitian ini adalah pendekatan kualitatif. Pendekatan kualitatif merupakan pendekatan yang memanfaatkan sistem wawancara terbuka untuk menelaah dan memahami sikap, pandangan, perasaan dan perilaku individu atau sekelompok orang. Penelitian ini mendeskripsikan tentang bagaimana sistem kerja karyawan front office dalam impementasi konsep 3B (Brain, Beauty and Behavior).

Pendekatan yang digunakan adalah pendekatan kualitatif. Pendekatan kualitatif merupakan pendekatan yang memanfaatkan sistem wawancara terbuka untuk menelaah dan memahami sikap, pandangan, perasaan dan perilaku individu atau sekelompok orang. 
Jenis penelitian yang digunakan adalah jenis penelitian deskriptif yang didukung dengan data kualitatif. Penelitian kualitatif lebih mementingkan suatu makna dan tidak ditentukan oleh kuantitasnya, di mana data yang dikumpulkan terutama kata-kata, kalimat, atau gambar yang memiliki lebih dari sekedar angka atau frekuensi/jumlah, dengan demikian laporan penelitian akan berisi kutipan. Kutipan data untuk memberi gambaran penyajian laporan yang mungkin berasal dari naskah wawancara, catatan, lapangan, foto, videotape, dokumen pribadi, catatan atau memo, dan dokumen resmi lainya (Moleong, 2004:11).

Teknik pengumpulan data yang digunakan dalam penelitian ini mengacu kepada teknik pengumpulan data kualitatif. Terdapat dua teknik pengumpulan data. Wawancara adalah merupakan pertemuan dua orang untuk bertukar informasi dan ide melalui tanya jawab, sehingga dapat dikonstruksikan makna dalam suatu topik tertentu, yakni melalui observasi terhadap aktivitas pelayanan karyawan Front Office kepada nasabah, serta wawancara medalam yang dilakukan kepada obyek penelitian, yaitu karyawan Front Office, serta kepada beberapa nasabah yang telah dipilih berdasarkan kriteria snow ball sampling.
Teknik analisis yang digunakan, yakni reduksi data, di mana peneliti mengambil data - data valid melalui wawancara dan observasi yang nantinya akan dideskripsikan kedalam narasi pada bagian pembahasan.

\section{HASIL DAN PEMBAHASAN Konsep Brain, Beauty, and Behavior pada karyawan Front Office Ability to Communicate: Brain;}

Brain secara harfiah mengandung pengertian "otak". Perlu ada pemahaman yang lebih terkait pengertian otak itu sendiri. Secara teori menyebutkan bahwa tolak ukur kecerdasan tidak hanya diukur melalui intelligence quotient (IQ), namun juga pada emotional quotient (EQ). Biasanya bagian HR (Human Resources) dalam sistem perekrutan karyawan memiliki sistem penilaian terhadap dua kecerdasan tersebut diatas terhadap calon karyawannya ini. Intelligence quotien (IQ) mengacu kepada bagaimana kemampuan karyawan secara intelektual dan emotional quotient (EQ), lebih menekankan kepada bagaimana pola sikap, kepribadian dan ketahanan secara emosional dari karyawan dalam menghadapi setiap tekanan dalam pekerjaan.

Dalam dunia kerja yang semakin kompetitif, kemampuan seseorang menangani beban kerja, 
stres, interaksi sosial, pengendalian diri menjadi kunci penting dalam keberhasilan perusahaan atau instansi. Seseorang yang sukses dalam pekerjaan biasanya adalah orang yang mampu mengelola dirinya sendiri, memotivasi diri sendiri dan orang lain, dan secara sosial memiliki kemampuan dalam berinteraksi secara positif dan saling membangun satu sama lain. Untuk itu penerapan kecerdasan lewat pola komunikasi yang baik, pola pergaulan yang baik, itu sangat penting. Berdasarkan hasil wawancara yang dilakukan, ditemukan bahwa, kapasitas kemampuan intelektual yang kadang menjadi prioritas dalam perekrutan karyawan, ternyata tidak memberikan jaminan dalam kemampuannya terkait implikasi didunia kerja. Secara praktis di dunia kerja, kapasitas brain menyiratkan tidak hanya sekedar memiliki kemampuan intelektual secara akademis saja, Kecerdasan secara emosional ternyata menjadi prioritas atau tolak ukur bagaimana penilaian terhadap kinerja dari karyawan tersebut. Ketiga hal tersebut yakni:

a. Self- awareness atau kesadaran diri

Berbicara mengenai tingkat kesadaran seseorang akan dirinya sendiri, termasuk kelebihan dan kekurangan yang dimiliki dirinya tersebut.
Seseorang yang memiliki kesadaran diri yang tinggi akan paham bagaimana hal-hal tersebut dapat berdampak pada orang lain secara baik dan positif. Umumnya, orang dengan kesadaran diri yang baik juga dapat mengatasi kritik dari orang lain dengan baik..

Implementasi gaya berkomunikasi pada setiap karyawan dalam dunia perbankan sebenarnya memiliki standar yang relatif sama. Bahwa hakikat berkomunikasi merupakan bagian penting dalam memberikan pelayanan yang prima. Kesadaran diri yang baik akan memberikan fungsi kontrol yang baik pula pada bagaimana upaya memuaskan customer atau nasabah. Self awareness memberikan jaminan bagi karyawan, khususnya yang menempati posisi front office dalam mengatur pola komunikasi baik secara verbal maupun non verbal.

Basic pertama yang harus dimiliki oleh seorang Public Relations Officer 
adalah

memiliki

manajemen komunikasi

yang baik. Kemampuan

dasar komunikasi ini

penting, karena pekerjaan

PR bersinggungan

langsung dengan opini publik. Manajemen

reputasi akan dikelola dengan baik, jika PRO mampu menempatkan prinsip - prinsip tersebut diatas untuk menjawabi semua kebutuhan informasi dari stakeholders, khususnya kepada nasabah.

b. Self- regulation atau kemampuan mengekspresikan diri

Berbicara mengenai kemampuan seseorang agar mampu mengatur kapan dan bagaimana ia mengekspresikan

perasaannya khususnya perasaannya kepada orang lain. Orang dengan kemampuan mengekspresikan diri yang baik biasanya dapat menyalurkan emosinya dan berkomunikasi dengan cara yang dewasa dan terlatih dalam menahan emosi tersebut jika perlu. Salah satu indikasi dalam self regulation atau kemampuan

mengekspresikan diri, yakni pada knowledge atau pengetahuan, seorang pekerja front office wajib memiliki pengetahuan yang excellence terkait semua aktivitas perusahaan yang berhubungan dengan produk dan jasa yang ingin diketahui oleh nasabah. Sedangkan pengetahuan yang excellence tersebut akan berguna jika didukung dengan etika penyampaian kepada nasabah atau customer dengan baik pula. Kemampuan mengekspresikan diri menjadi fondasi kuat dalam pemenuhan kepuasan nasabah dari segi keterpenuhan keinginan akan produk dan jasa oleh nasabah atau customer. Dari hasil pengumpulan data yang dilakukan, didapati bahwa pekerjaan front office, rentan terhadap berbagai masalah komunikasi yang terjadi. Ekspektasi nasabah akan layanan yang prima dan cepat, menuntut setiap pekerja front office untuk bekerja cepat dan reaktif. 
Front Office harus mampu menjaga relasi komunikasi yang baik kepada nasabah, khusunya pada nasabah yang minim pengetahuan tentang produk atau jasa yang dimiliki oleh bank tersebut, atau pada nasabah yang melakukan komplain atas pelayanan yang dirasa tidak sesuai dengan harapan dari mereka. Knowledge atau pengetahuan yang baik bagi seorang pekerja front office harus memiliki muatan standar pada unsur seperti kecakapan dalam komunikasi verbal, yakni bagaimana artikulasi dan kemampuan pemilihan bahasa yang baik dan jelas, sehingga segala informasi terkait apa yang dibutuhkan oleh nasabah dapat tersampaikan dengan baik. Oleh karena itu, knowledge harus diimbangi dengan skill berkomunikasi yang tepat. Salah satunya melalui pemilihan kalimat yang mampu mengedukasi, menginformasikan, hingga dapat mempersuasi nasabah terkait produk dan jasa dari bank tersebut.
Fronf Office harus memiliki responsibility yang baik, sehingga mampu mendeteksi keinginan dan kebutuhan nasabah dalam waktu yang singkat.

c. Keterampilan interpersonal atau people skills

Berbicara mengenai kemampuan seseorang dalam membangun interaksi dan kepercayaan dengan orang lain dalam sebuah tim atau unit kerja. Dengan keterampilan interpersonal yang mumpuni, orang-orang pun dapat berelasi dan mengerjakan tugasnya dengan lebih baik, terutama karena sekarang semua serba bergantung pada komunikasi yang baik.

Bekerja pada lini front office berarti siap menghadapi segala konsekuensi yang datangnya dari nasabah. Pada prinsipnya, nasabah adalah pihak yang tidak mau tahu dalam kondisi 
apapun, segala kebutuhan, keinginan dan bahkan keluhan harus direspon cepat oleh petugas bank yang ia temui. Analisis kebutuhan nasabah memiliki berbagai tingkatan yang berbeda. Pemetaan nasabah dibagi berdasarkan jumlah dan besaran investasi yang dipercayakan nasabah kepada bank tersebut. Ada sebagian nasabah yang masuk dalam tipe nasabah prioritas yang mana secara kualitas dan mutu pelayanan mesti mendapatkan service yang prima, mulai dari waktu dan tempat yang sengaja diberikan oleh pihak bank.

Robinson

(dalam

Goldhaber, 1990:89) mendefinisikan publik sebagai sekelompok orang yang memiliki kepentingan yang sama. Sementara pesan publik adalah yang ditujukan untuk mencapai banyak orang atau yang berpotensi mencapai banyak orang. Kondisi seperti inilah yang menuntut kerja cepat dan reaktif dari front office sebagai problem solver.
Memahami psikologis setiap nasabah, khususnya dalam menyikapi keluhan dan ketidaktahuan nasabah menjadi sebuah keharusan bagi pekerja front ofiice. Hasil wawancara kepada nasabah, didapatkan informasi bahwa, harapan nasabah terkait sistem pelayanan dalam dunia perbankan mengacu kepada dua hal, yakni waktu, bagaiamana efektifitas waktu yang cepat dalam merespon nasabah, serta solusi yang diberikan, harus mampu menjawab apa yang dibutuhkan nasabah. Kedua hal tersebut menjadi acuan bagi penilaian kerja front office.

Menyadari bahwa nasabah memiliki latar belakang pendidikan, pekerjaan, serta karakter yang berbeda, diharapkan mampu memberikan solusi bagi front office, untuk bagaimana mengintegrasikan segala perbedaan ini ke dalam suatu bentuk service yang excellence. 
Mampu mengorganisir komplain dari nasabah, menjadi bagian dari konsep brain pada 3B. Perlu disadari bahwa, pengetahuan dan skill tidak hanya sekedar pada pertukaran informasi, namun lebih dari itu kemampuan untuk dapat mengorganisir persoalan yang terkait dengan perusahaan dan publiknya menjadi tolak ukur kompetensi seorang public relations officer

\section{Beauty}

\section{Personal Integrity.}

Mengkaji tentang "beauty" pada brain, beauty and behavior, mengacu kepada konsep "cantik" itu sendiri yang berarti fisik yang baik dan sempurna. Apalagi jika pekerjaan yang mengharuskan untuk selalu berhubungan dan berintekarsi dengan banyak orang dari berbagai tingkatan. Kodisi fisik menjadi daya tarik tersendiri dalam prospek sebuah produk ataupun jasa kepada calon customer. Tidak dapat dipungkiri bahwa pekerjaan yang berhubungan dengan dunia perbankan biasanya di dominasi oleh para pekerja yang berparas cantik dan menarik. Banyak orang berkata “Don't judge the book by its cover", namun kenyataan hidup yang kita hadapi selalu dinilai berdasarkan apa yang kita lihat.
Menciptakan kesan pertama yang positif dengan tetap berpenampilan terbaik, maka seorang karyawan dapat menjadi pribadi yang menarik pula. Setiap karyawan sangat menyadari bahwa begitu pentingnya momen kesan pertama dalam hal apapun. Tidak hanya dari sikap, tetapi juga tentunya penampilan atau gaya berbusana seseorang.

Sudah menjadi sifat manusia bahwa mereka suka menilai orang berdasarkan apa yang mereka lihat. Manusia cenderung merumuskan pendapat awal tentang seseorang bahkan sebelum mereka benar-benar berbincang-bincang bersama. Hal tersebut menandakan bahwa pakaian yang kita kenakan akan memiliki efek langsung pada asumsi setiap orang tentang kita. Pakaian dapat meningkatkan status sosial di lingkungan pekerjaan. Pakaian yang di kenakan dapat membantu meningkatkan reaksi nasabah atau customer terhadap karyawan khususnya pada lini pekerjaan yang langsung bersinggungan dengan banyak orang. Lingkungan sosial adalah suatu hal yang pada dasarnya sangat erat kaitannya dengan masalah visual. Seseorang yang berpakaian baik biasanya akan lebih mengalami perlakuan yang lebih baik ketimbang seseorang yang berpenampilan biasa saja. Tidak peduli orang tersebut siapa dan apa jabatannya. 
Pakaian yang kita kenakan dapat menunjukkan karakter kita di mata para orang-orang asing yang belum mengenal kita lebih dalam pada suatu lingkungan sosial. Karena dalam lingkungan sosial dengan banyak orang asing di dalamnya, mereka tidak bisa menilai kita lebih dalam sebelum berinteraksi kecuali dari penampilan kita. Berpenampilan terbaik membantu meningkatkan rasa percaya diri. Sedangkan Dalam Cambridge Dictionary, Beauty berarti the quality of being pleasing, especially to look at". Kata kunci dari beauty adalah "tampak oleh mata". Dalam kehidupan berinteraksi, penampilan fisik itu penting sekali. Berpenampilan menarik adalah berpenampilan yang sejujur-jujurnya namun bisa menempatkan diri. Penampilan seorang front office yang baik dan menarik akan memberikan persepsi yang positif terhadap orang lain yang bertemu dengan mereka. Selain itu hal tersebut menyangkut kesan pertama calon atau customer terhadap produk atau jasa yang kita pasarkan.

Penampilan tak bisa dipungkiri adalah cerminan sosok dan citra diri yang sangat berperan terhadap penilaian orang lain terhadap seseorang bahkan dalam berbagai hal, penampilan bisa menjadi 'modal utama' agar tidak dipandang sebelah mata relasinya. Pentingnya cita rasa dalam berpenampilan itulah yang membuat apa yang dikenakan menjadi hal yang harus mendapat porsi tersendiri oleh setiap orang. Tak hanya dalam kehidupan pribadi maupun sosial, tapi juga mencakup kehidupan karir seseorang. Penampilan dapat dikatakan sebagai satu bagian penting terkait pembentukan citra profesional serta memberi rasa kepercayaan diri yang tinggi untuk mengekspresikan kompetensi yang dimiliki. Penampilan memberikan persepsi mengenai pribadi seseorang secara tidak langsung melalui penampilan luar, orang lain dapat memberikan persepsi tersebut berdasarkan apa yang ia lihat, ia cerna dan menjadi sebuah gambaran mengenai pribadi individu tersebut.

Wawancara yang dilakukan kepada beberapa nasabah dari berbagai bank secara silang ditemukan bahwa, keputusan nasabah untuk berinvestasi adalah salah satunya dari daya tarik fisik dan pelayanan ramah yang diberikan front office suatu bank. Namun ada juga yang berpendapat berbeda, menurut beberapa nasabah definisi cantik itu bukan pada paras semata, harus putih, langsing, berpostur tinggi ternyata tidak memberikan jaminan pada kepuasan nasabah, jika tidak didukung dengan kecakapan verbal dan gesture yang baik. Melalui 2 pernyataan yang berbeda ini, peneliti berupaya untuk mengaitkan konsep 
beauty ke dalam salah satu kuaifikasi PR, yakni personal integrity. Kualitas yang disebut "cantik" benar - benar ada, secara objektif dan universal. Dalam kajian profesi PR, konsep cantik tidak hanya daya tarik fisik, namun lebih dari itu seorang PRO dituntut untuk memiliki kredibilitas yang tinggi pada kepribadian. Kepribadian yang beretika dapat diukur ke dalam 2 aspek:

a. Personality. Setiap bank berlomba - lomba menghadirkan layanan prima melalui produk dan jasa yang ditawarkan kepada nasabah. Berdasarkan hasil penuturan karyawan yang bekerja pada bagian Customer Service pada salah satu Bank Daerah di Kabupaten Sikka, profesionalisme dalam bekerja menjadi prioritas bagi karyawan front office. Implementasi senyum, salam, sapa menjadi bagian penting dalam memberikan pelayanan kepada nasabah. Selain itu membuka obrolan terkait apa yang butuhkan nasabah dengan pemilihan bahasa yang santun dan bersahabat selalu ditanamakan dalam diri setiap karyawan, khuusnya yang bekerja pada lini depan. Personality memegang kendali penting pada sistem pelayanan dalam dunia perbankan.

b. Etika berbusana. Selain personality yang baik, daya tarik karyawan front office sendiri terletak pada keselarasan dan kesesuaian pemilihan busana serta make up yang digunakan. Seragam yang dikenakan, dalam paduan warna, serta model menjadi penilaian tersendiri dari nasabah. Tidak hanya terkait busana yang dikenakan, pemakaian soft make up serta pemilihan aksesoris juga turut berkotribusi dalam mendukung penampilan karyawan front office. Tidak 
mengherankan jika banyak

nasabah yang berpendapat

jika pelayanan karyawan

bank sangat ditunjang oleh

penampilan yang menarik.

Terkait dengan etika

berpenampilan, dalam

pembahasan ini peneliti

merasa perlu untuk

memaparkan tentang

konsep beauty dalam

perspektif karyawan laki -

laki dan karyawan

perempuan. Jika dahulu

ada anggapan yang

menyebutkan bahwa

pekerjaan yang

berhubungan dengan daya

tarik fisik serta pekerjaan

yang memikirkan etika

penampilan merupakan

pekerjaan

yang

berhubungan dengan

wanita, maka anggapan

tersebut dipatahkan jika jita

melihat pada sistem kerja

dunia perbankan yang

banyak dijumpai karyawan

laki - laki yang juga

memiki skill serta kemampuan seperti wanita.

Konsep beauty bagi karyawan wanita lebih

dititik beratkan kepada penggunaan make up serta penggunaan aksesoris, maka karyawan laki - laki leibh melihat kepada bagaimana penggunaan seragam atau pakaian kerja yang rapih, serasih serta sedikit penggunaan aksesoris pendukung dalam meningkatkan citra diri dan penampilan.

Dalam penelitian ini, terkait dengan etika berbusana, peneliti juga mengkaji sebuah gaya berbusana yang cukup menarik yang dikenakan oleh karyawan bank yang ada di Kabupaten Sikka, yaitu penggunaan pakaian daerah yang mampu menjadi brand identity bercita rasa kearifan lokal.

Melalui peraturan pemerintah daerah (PERDA) yang menetapkan hari berbusana daerah Nusa Tenggara Timur bagi seluruh karyawan baik yang berada pada lingkungan pemerintah daerah maupun swasta, menjadi stimuli tersendiri tentunya bagi karyawan bank yang ada di Kabupaten Sikka untuk berlomba lomba menunjukkan eksistensi 
kedaerahannya melalui pakaian daerah yang dikenakan pada satu hari dalam setiap minggunya. Peneliti melihat konsep pakaian daerah yang dikenakan menjadi sebuah nilai jual secara intangible product bagi bank tersebut di mata nasabah atau customer. Cita rasa kedaerahan yang cukup beragam yang dimiliki oleh setiap kabupaten yang ada di provinsi Nusa Tenggara Timur, turut menumbuhkan "branding orang NTT" yang cinta daerah melalui apa yang dikenakan oleh karyawan bank. Tentunya diharapkan penggunaan atribut daerah ini turut meningkatkan loyalitas nasabah terhadap bank tersebut dalam berinvestasi serta dalam bertransaksi dalam jasa keuangan. Behavior

\section{Ability to get on with people}

Publik (khalayak) adalah kelompok atau orang - orang yang berkomunikasi dengan suatu organisasi, baik secara internal maupun eksternal (Jefkins, 2003:89). Menjaga agar hubungan internal maupun ekternal bersama publik tidak terabaikan menjadi salah satu fungsi PR, yakni sebagai "jembatan" antara perusahaan atau organisasi dengan publiknya, sehingga tercapai yang namanya mutual understanding. Untuk sampai pada konsepsi pemahaman dari nasabah atas kinerja perusahaan maka PR harus mampu membangun konektifitas yang baik kepada segenap stakeholders.
Kemampuan membina relasi juga penting bagi profesi front office.

Tidak jauh berbeda dengan personal integrity, karyawan front office mesti memiliki jaringan relasi yang baik serta rasa empati yang tinggi terhadap nasabah. Kesan pertama yang dirasakan nasabah adalah melalui kemampuan front office dalam memberikan good service kepada nasabah, karena perlu disadari bahwa nasabah atau customer merupakan aset besar bagi tumbuh kembang sebuah perusahaan. Dari hasil pengumpulan data, maka peneliti membagi kemampuan membina relasi melalui beberapa bagian, yakni:

a. Meningkatkan kepuasan nasabah

Perlu disadari bahwa kepuasan nasabah merupakan hal yang penting dalam menjaga hubungan baik dengan mereka. Ketika seorang nasabah memutuskan untuk berinvestasi atau menggunakan layanan dari sebuah bank, tentu mereka menginginkan kualitas yang bagus bukan hanya dari produk yang ditawarkan, namun juga 
pada pelayanan yang diberikan. Meningkatkan kepuasan nasabah dibutuhkan perasaan yang peka, yang mampu mendeteksi apa yang mereka butuhkan. Penelitian ini sejalan dengan penelitian Fornell (1992) dalam Tesis “Analisis Faktor - Faktor yang Mempengaruhi Kepuasan Nasabah Dalam Meningkatkan Loyalitas Nasabah" oleh Novel Fatrio, yang mengatakan bahwa kepuasan nasabah memengaruhi perilaku membeli, di mana nasabah yang puas cenderung menjadi nasabah yang loyal, namun nasabah yang tidak loyal tidak perlu puas.

b. Melayani nasabah dengan baik dan ramah

Tidak dapat dipungkiri, terkadang front office harus berhadapan dengan nasabah yang "menyebalkan", memiliki keinginan untuk diprioritaskan terlebih dahulu dengan mengenyampingkan segala aturan yang ada, saat itulah kredibilitas seorang front office diuji. Ekspresi wajah yang harus selalu ramah dan senantiasa selalu tersenyum serta kontak mata perlu dijaga oleh front office. Menurut Wenburg dan Wilmot (dalam Deddy Mulyana, 2008:373) kontak mata mempunyai dua fungsi dalam komunikasi antarpribadi. Pertama, fungsi pengatur, untuk memberitahu orang lain apakah kita akan melakukan hubungan dengan orang itu atau menghindarinya. Kontak mata mesti selalu diarahkan kepada nasabah, agar mereka tahu bahwa mereka siap dilayani dalam kondisi apapun.

c. Selalu menanyakan apa yang dibutuhkan oleh nasabah.

Tidak menyela atau memotong pembicaraan, mengucap salam, mengucapkan salam pada saat bertemu dengan nasabah, seperti selamat pagi, selamat siang, atau selamat sore. Minimal nama nasabah disebutkan 
tiga kali jika sudah mengetahui nama nasabah. Mempersilahkan nasabah, setelah mengucapkan salam, segera mempersilakan nasabah untuk masuk atau duduk dengan sopan. Bertanya tentang keperluan nasabah setelah dipersilakan duduk, barulah karyawan bertanya tentang maksud kedatangan nasabah secara ramah, sopan, dan lemah lembut. Misalnya "Ada yang bisa saya bantu, bapak atau ibu". Bila ingin menyuruh, untuk hal-hal yang dianggap perlu, biasakan menyuruh nasabah dengan mengawali ucapan "tolong" atau "maaf", serta selalu mengucapkan terima kasih. Contoh di atas merupakan etika berkomunikasi bagi setiap karyawan front office, dimulai dari security sampai customer service.

Front office merupakan posisi pertama yng ditemui nasabah ketika mendatangi sebuah bank. Selalu menanyakan apa saja yang butuhkan, dikeluhkan oleh nasabah merupakan poin penting dalam pelayanan, serta mengukur kualitas produk dan jasa. Ini merupakan bagian dari strategi dalam membangun relasi yang baik dengan nasabah.

\section{Imagination}

Imajinasi bagi seorang pekerja PR mengandung pengertian memiliki kreatifitas dalam memberikan ide, dalam pengertian PRO harus memiliki wawasan yang luas, dan mampu menyelesaikan persoalan dengan bijak. Seorang PR mesti mengasah kemampuan, serta keterampilan yang dimiliki karena perlu disadari bahwa dengan kondisi masyarakat yang semakin kritis, perkembangan teknologi informasi yang pesat, persaingan antar bank yang tak terhindarkan, maka sentuhan dari seorang PR menjadi sebuah penentu opini publik.

Pada pekerjaan front office sendiri, tuntutan memiliki kreatifitas dalam memberikan solusi yang dibutuhkan oleh nasabah adalah didasarkan keberadaannya pada lini terdepan dari suatu bank, yakni salah satunya sebagai problem solver terhadap berbagai keluhan dan kebutuhan informasi dari nasabah. Meskipun hasil temuan di lapangan melalui wawancara kepada beberapa nasabah, didapatkan bahwa terkadang nasabah merasa tidak terpuaskan dalam sistem pelayanan di bank, namun petugas front office akan bertindak cepat untuk mengatasi segala keluhan yang ada.

Bekal utama yang dimiliki sebagai salah satu kualifikasi front 
office dalam point imagination adalah wawasan dan pemahaman terhadap karakteristik nasabah serta menguasai konsep, implementasi dalam pemecahan setiap masalah secara tanggap dan cepat.

Berpikir kreatif serta imajinatif, menuntut sumber daya manusia yang handal bagi pekerja front office. Karena aktivitas memasarkan produk dan jasa yang dilakukan secara konvensional melalui komunikasi tatap muka secara langsung dengan nasabah, menuntut kesesuaian dari brain, beauty and behavior, maka posisi seorang fornt office menjadi nilai jual bagi kredibilitas sebuah industri perbankan.

\section{SIMPULAN}

Dari hasil kajian pada pembahasan, maka berdasarkan judul tentang Konsep Brain, Beauty and Behavior pada Profesi Public Relatios, peneliti dapat mengambil beberapa simpulan, yakni:

Konsep brain mengandung 2 pemahaman dalam kualifikasi PR, yakni ability to communicate dan Personal integrity. Kedua kualifikasi ini, memiliki pengertian tidak hanya pada tatanan otak sebagai suatu media mengukur kemampuan secara akademik semata, namun lebih dari itu, pekerjaan sebagai front office, menuntut adalahnya knowledge yang berarti pengetahuan atau berwawasan luas terkait budaya perusahaan yang di dalamnya memuat produk dan jasa serta skill berkomunikasi yang menjadi nilai jual dari front office.

Berikutnya, konsep beauty. Cantik bukan hanya definisi tentang rupa yang menawan, namun lebih dari itu, beauty merupakan personal integrity, di mana cakupan dari personal integrity ialah keselarasan dalam mengimplementasikan apa yang dikenakan dengan apa yang tampilkan. Bekerja pada lini front office berarti siap menghadapi konsekuensi untuk dinilai berdasarkan kesesuaian antara tampilan fisik, dengan kepribadian yang ramah dan bersahaja.

Serta yang terakhir konsep behavior, menyiratkan makna bahwa kehadiran front office mampu menjembatani segala kebutuhan dan keinginan dari nasabah. Memiliki pemahaman yang lebih kepada nasabah, menuntut seorang front office harus mampu menjalin relasi dan menjadi mitra yang baik saat sedang menjamu customer. 3 konsep penting dalam membina relasi ialah dengan selalu meningkatkan kepuasan nasabah, selalu melayani nasabah dengan baik dan ramah serta selalu menanyakan apa yang dibutuhkan oleh nasabah. Behavior tidak hanya sebatas memiliki relasi yang baik, namun juga tuntutan akan kreatifitas dalam memberikan solusi seta ide kepada nasabah juga menjadi 
bagian penting dari kerja front office. Selalu siap dalam setiap suasana dan kondisi nasabah yang tidak sama, turut berkontribusi terhadap penilaian terkait perilaku dari seorang front office.

\section{UCAPAN TERIMA KASIH}

Penelitian ini tidak akan terselesaikan tanpa adanya bantuan dan dorongan dari berbagai pihak baik berupa moril, serta rekomendasi dan izin penelitian. Untuk itu pada kesempatan ini peneliti menyampaikan penghargaan dan terima kasih yang sebesar - besarnya kepada Yayasan Pendidikan Tinggi Nusa Nipa, Rektor Universitas Nusa Nipa. Pimpinan dan karyawan Front Office (Security, Teller, Customer Service) dari bank - bank yang ada di Kabupaten Sikka, BNI 46, BRI dan Bank NTT yang telah memberikan kesempatan, menerima dan mendukung dalam proses penelitian hingga terselesaikan. Semua pihak yang tidak dapat disebutkan satu persatu dengan caranya masing masing telah memberikan dukungan dalam bentuk apapun dalam penyelesaikan penelitian ini.

Akhir kata peneliti berharap semoga penelitian ini dapat bermanfaat bagi semua pihak yang membutuhkan dan semoga Tuhan Yang Maha Esa selalu senantiasa melimpahkan berkat dan rahmatNya kepada kita semua.

\section{DAFTAR PUSTAKA}

Buku :

Ardianto, E. (2004). Public Relations: Suatu Pendekatan Praktis Kiat Menjadi Komunikator dalam Berhubungan dengan Publik dan Masyarakat. Bandung: Pustaka Bani Quraisy

Abdullah, Irwan. (2006). Studi Tubuh, Nalar dan Masyarakat: Perspektif Antropologi. Yogyakarta: Tici Press

Goldhaber, Gerald M. 1990. Organizational Communication $5^{\text {th }}$ ed., Dubuge, IA: Wm C Brown Publisher

Jefkins, F. (2003). Public Relations: Edisi Kelima. Jakarta: Penerbit Erlangga

Kriyantono, R. (2008). Public Relations Writing. Jakarta: Kencana Prenada Media Group

Kasmir. (2014). Dasar - dasar Perbankan. Jakarta: PT. Rajagrafindo Persada

Kotler, Keller. 2012. Marketing Manajemen, $14^{\text {th }}$ ed., Pearson Education

Moleong, L. (2004). Metodologi Penelitian Kualitatif (edisi revisi). Bandung: Remaja Rosdakarya

Mulyana, D. (2008). Ilmu Komunikasi Suatu Pengantar. Bandung: Remaja Rosdakarya 
Ruslan, R. (2008). Kiat dan Strategi Kampanye Public Relations. Jakarta: PT. Remaja Rosdakarya (2004). Metodologi Penelitian Kualitatif. Bandung: PT Remaja Rosdakarya

Yulianita, N. (2001). Dasar - Dasar Public Relations. Bandung: Lab Multimedia Fikom Unisba

\section{Sumber lain :}

Ardilla, Sheilla. (2013). Konsep $4 b$ (Brain, Beauty, Behavior, Brave) Di Mata Publik (Studi Deskriptif Kualitatif Tentang
Persepsi Nasabah Terhadap Konsep $4 b$ Pada Karyawan Frontliner Bank Panin KCU Kota Kediri). Jurnal Universitas Brawijaya Malang.

Novel, Satrio. (2006). Analisis Faktor - Faktor Yang Mempengaruhi Kepuasan Nasabah Dalam Meningkatkan Loyalitas Nasabah (Studi Kasus pada Bank Bukopin Kantor Cabang Tegal). Tesis Pascasarjana Manajemen Universitas Diponegoro 